\title{
Farmer-led Improved Storage Technique and Management of Aflatoxin in Peanut Production: Evidence from Ghana
}

Edward Martey* and Prince M. Etwire

CSIR-Savanna Agricultural Research Institute

*Corresponding: eddiemartey@gmail.com; Edward Martey, P. O. Box TL52 Tamale, Northern

Region, Ghana

\begin{abstract}
Peanut production contributes to food security in northern Ghana due to its ability to tolerate drought and survive on marginal lands. This notwithstanding, poor handling along the value chain favors aflatoxin contamination, a threat to human and animal life. Farmer-led improved storage practice, a potential solution to aflatoxin contamination, have been promoted in northern Ghana. However, there is limited evidence on the factors influencing the use of the improved storage system that may guide dissemination efforts. Using the Cragg's two stage model, our results show that the probability and intensity of adopting the improved storage structure is principally and significantly influenced by economic active household members, storing of peanut in other places relative to the field, and location of farmer residence. In disseminating the improved peanut storage structure, the identified factors must be incorporated in the selection criteria to ensure maximum uptake and usage. Farmer training programs that incorporate both good agronomic practices and good storage practices must be intensified to reduce postharvest losses due to aflatoxin contamination. These strategies will help mitigate the harmful effect of aflatoxin, ensure economic sustainability, and enhance food security.
\end{abstract}

Keywords: improved storage structure; aflatoxin; peanut; Cragg's model; Ghana 


\section{Introduction}

World peanut production has been increasing at an annual rate of 2.5\% from 1972-2000 due to increase in area under cultivation and yields. Nevertheless, variations exist in the regional production of peanut with Asia contributing largely to the world growth in production followed by Africa, and North America (Fletcher and Shi, 2016). Within Africa, a large share of the production growth is contributed by West Africa and the trend is expected to continue to increase. According to Pazderka, and Emmott (2010), Nigeria, Senegal, and Ghana are among the top ten global producers and occupy $12 \%$ of the market. Despite low yields in developing countries, the world peanut production continue to increase (Fletcher and Shi, 2016).

A study by Annigan, (2014) show that death is the result of extreme levels of protein deficiency. This phenomenon is common in Sub Saharan Africa (SSA) where most young children are malnourished. Peanut has high protein content and a potential source of addressing the high levels of malnutrition. Notwithstanding the importance of the crop, the raw materials and transformed products are susceptible to colonization by fungal molds during post-harvest handling, storage, and transportation (Mutegi et al., 2013; Villa and Markaki, 2009). Aflatoxin contaminated peanut poses severe threat to the livelihood of humans and animals, thus there is the need to reduce the contamination through the use of production and post-production techniques to enhance the wellbeing of humans and animals. 
Aflatoxin is an extremely toxic chemical produced primarily by the fungus Aspergillus flavus in food crops such as maize and peanuts (Atehnkeng et al., 2008; Bankole et al., 2006). The infestation occurs during pre and post-harvest stages of the crop (Kaaya et al., 2006). For example, the Food and Agriculture Organization (FAO) of the United Nations (UN) estimated that the 25\% of the world's crop production are contaminated with mycotoxins at different stages of the value chain (Wu, 2007). The consumption of aflatoxin contaminated peanut poses serious threat to the health of both humans and animals. Women, children and the poor are predominantly susceptible. The situation could also lead to insurmountable barriers to trade leading to lower revenues. For example, the United States enforces a maximum acceptable limit of aflatoxin at $20 \mu \mathrm{g} / \mathrm{kg}(\mathrm{Wu}$, 2006) whiles the European Union (EU) strictly enforces a maximum acceptable limit of aflatoxin at $4 \mu \mathrm{g} / \mathrm{kg}$ (EC, 2007). These standards require innovative ways to reduce the level of contamination.

Improved storage system is among the strategies employed to reduce the contamination, however, understanding the dynamics of socio-economic factors, farming system, postharvest practices, and spatial differences in production will enhance promotion of the technique to smallholder farmers. This study seeks to identify factors influencing the use of improved storage structure that has been widely promoted in peanut production districts in northern Ghana. Several studies in SSA have identified production and postharvest practices that contribute to improving peanut contamination. Pankaj et al. (2018) demonstrate that technologies such as pulsed light, electrolyzed water, and cold plasma are effective in preventing aflatoxin on different substrates and recommend application of the technologies to food products. A study by Udomkun et al. (2017) show that biological control (use competitive exclusion of toxigenic strains by non-toxigenic ones) is the 
most innovative potential technology for controlling aflatoxin in peanut. Achaglinkame et al. (2017) suggests that aflatoxin contamination in cereals and legumes can be achieved through awareness creation, education, good agricultural practices and proper storage practices. They further suggest that complementary feeding should focus on tuber-based blends rather than cereallegume blends to prevent the adverse effect of aflatoxin among infants and children in Ghana. Mutegi et al. (2013) assess the storage conditions on the quality and aflatoxin contamination of peanut using controlled experiment in Kenya. They propose the use of container for storing dried peanuts in a well-ventilated room to reduce high levels of aflatoxin.

Most of the studies on peanut in Africa are centered on agronomic and postharvest technologies and practices. Despite the vast literature on improved storage structure, there is limited information on the factors influencing the intensity of use of farmer-led improved storage technique in reducing aflatoxin infestation. Understanding the demographic and socio-economics factors is necessary for developing appropriate strategies for effective targeting and promotion of improved technologies. Identifying the factors that influence the adoption of improved storage technique will not guarantee a strong policy for food security if barriers to the consistent use and intensification are not adequately identified. This study is among the first to identify the factors that determine the intensity of using farmer led improved storage structure using Ghana as a case study. The outcome of this study will guide future promotion technologies in SSA.

The remainder of the paper is organized as follows: In the next section, we present the materials and methods. Section 3 reports the findings and discusses the results. Section 4 summarizes and concludes the paper. 


\section{Materials and Methods}

\subsection{Study area, sampling and data description}

The study cover smallholder peanut farmers located in the Guinea and Sudan savannah agroecological zones (Figure 1). The regions have estimated population of 4,228,116 (Ghana Statistical Service, 2012) and poor compared to the rapidly developing and urbanization south (Gage et al. 2012). The regions record a unimodal annual average rainfall of about 1000mm that lasts between five and six months (Owusu, 2018). This value is below the annual average rainfall in the rain forest and deciduous forest zones of Ghana. The climate provides a conducive environment for post-harvest handling of peanut thus making the crop one of the most profitable commercialized crop with gross profits of GHS2.5/ha (DAI, 2014). Figure 1 shows the districts of the study area. These districts represent the major peanut-producing areas in the country with high number of small-scale processors. Agriculture is the main source of livelihood among the majority of the inhabitants.

The data used for the study come from a farm survey of 320 farm household in the Guinea and Sudan Savanna agro-ecological zone of Ghana consisting of Northern, Upper East, and Upper West regions of Ghana. Data were collected by trained enumerators through interviews and focus group discussion. A multi-stage sampling technique was employed to sample the farmers. In the first stage, the target population unit was stratified and four districts (two in Northern Region and one each in Upper East and Upper West regions) were purposively selected based on the volume of peanut produced. In the second stage, five communities from the districts were purposively selected based on active participation of farmers in peanut production and active household 
members engaged in processing activities. In the third stage, 320 farmers (consisting of 241 males and 79 females) were randomly selected from the communities. One observation was dropped due to missing values, leaving us with 319 observations.

The study utilized primary data obtained from a survey conducted in the summer of 2014 using a semi-structured questionnaire. We conducted focus group discussion to identify the main practices associated with peanut production. This information was used to develop the farm household survey. The data captured per the study includes household demography and farm characteristics (farm size, cropping system, seed type, variety, timing of harvesting, and years of farming experience), knowledge of aflatoxin, production (quantity of peanut produced and contaminated by aflatoxin), and post-production practices (threshing, cleaning, transportation, drying, storage, and marketing). Adoption of farmer-led improved storage structure is a dummy and the intensity of adoption is measured by the number of seasons the improved storage structure is used.

[Figure 1]

\subsection{Descriptive statistics}

Table 1 reports the mean and standard deviation of the dependent variables (adoption of improved storage and the intensity of adoption) and the explanatory variables used in the model. The results show that $42 \%$ of the sampled farmers use the farmer-led improved storage structure for about 5 seasons on the average. The average age of a farmer in our sample is 40 years with 4 years of schooling and household size and economic active household members of 11 and 5 respectively. About $72 \%$ and $66 \%$ of the farmers rotate and intercrop respectively. Total peanut produced per household is $795 \mathrm{~kg}$ out of which $41 \mathrm{~kg}$ is affected by aflatoxin. The results indicate that $87 \%$ of the farmers harvest their peanut early within a period of five days after maturity. However, $33 \%$ of the farmers immediately harvest without interruption. We observe that while $67 \%$ of the sampled 
farmers are aware of aflatoxin, only $32 \%$ have knowledge of its control. Most of the farmers (67\%) store their peanut in the courtyard.

\section{[Table 1]}

Table 2 shows statistical significant difference between the production volume of peanut and the volume affected by aflatoxin based on knowledge of aflatoxin. Total production volume (923kg) and quantity affected by aflatoxin $(51 \mathrm{~kg})$ on the average is relatively higher for farmers who are aware of aflatoxin relative to farmers who are not. Table 3 compares the difference in mean total production and volume of peanut contaminated with aflatoxin based on awareness of aflatoxin control. The mean difference is statistically significant. The results indicate that farmers who have knowledge of aflatoxin control have higher production volume $(1014 \mathrm{~kg})$ and lower volumes of contaminated peanut $(28 \mathrm{~kg})$ relative to those who are ignorant of aflatoxin control. Our results emphasize the fact that awareness of aflatoxin is not a guarantee for taking preventive measures. Therefore, continuous training of farmers in aflatoxin control is crucial for reducing the losses and ensuring food safety among consumers.

\section{[Table 2 and 3]}

Figure 2 (panel A) shows the binscatter ${ }^{1}$ plot of the relationship between total peanut produced and the quantity contaminated by aflatoxin whiles figure 2 (panel B) shows the binscatter plot between number of days in harvesting peanut and the quantity of peanut contaminated with aflatoxin. After controlling for district fixed effects, we find that a more linear relationship exist between total production and quantity affected by aflatoxin for users of improved storage structure while a quadratic relationship between the two variables is observed for users of traditional storage

\footnotetext{
${ }^{1}$ Binned scatterplots are an informative and versatile way of visualizing relationships between variables (www.michaelstepner.com/binscatter).
} 
structure. In panel B of figure 2, we observe that quantity of peanut contaminated with aflatoxin decreases with the number of days of harvesting. This implies that delay in harvesting is likely to expose the crop to fungal attack. The linear relationship between the two variables is inelastic for users of traditional storage structure and elastic for users of improved storage structure. This means that for farmers who use traditional method of peanut storage, a small decrease in the number of harvesting days will lead to a more than proportionate increase in the quantity of peanut contaminated by aflatoxin. Peanut drying must be encouraged to reduce the quantity of peanut contamination.

[Figure 2]

We further explore the differences in the socio-economic, production, and post-harvest practices based on adoption of improved storage structure (Table 4). Adopters refer to farmers who use improved storage structure. The results show that $42 \%$ of the peanut producing households use improved storage structure. Farmers who use improved storage structure are significantly different from non-users in terms of marital status, cropping system (crop rotation), number of harvesting days, awareness of aflatoxin control, storage of peanut, and farmers' location. Relative to adopters, the non-adopters have relatively high $(90 \%)$ number of married farmers and spend more days in harvesting peanut after maturity. Nevertheless, adopters have more farmers who use crop rotation and are aware of aflatoxin control.

\section{[Table 4]}

Farm households were categorized into production quintiles to ascertain the heterogeneity in the relationship between production volume and the quantity affected by aflatoxin based on adoption status. Table 5 shows that the production volume of peanut for non-adopters of improved storage structure at the first $(101 \mathrm{~kg})$ and third $(550 \mathrm{~kg})$ quintiles are higher than the adopters. Both adopters 
and non-adopters recorded the same production volume at the second production quintile. Adopters within the fourth and fifth quintiles recorded higher production volume relative to nonadopters of improved storage structure. However, the average production volume of peanut is higher for adopters when compared to non-adopters of improved storage structure. Our results (Table 5) also show that with the exception of the fifth quintile, all the production quintiles of adopters recorded higher quantity of peanut affected by aflatoxin relative to non-adopters. This shows that use of traditional storage structure is associated with high post-harvest loss for farmers who belong to the fifth production quintile.

\section{[Table 5]}

\section{Empirical method}

\subsection{Conceptual framework}

Figure 3 shows the peanut postproduction system that connects different functions within the value chain. Reduction in the quantity and quality of peanut may occur at different stages within the postproduction system. This may start from production through harvest to consumption. Reduction in the amount of peanut produced is referred to as quantity loss which is a common phenomenon in developing countries (Kitinoja and Gorny, 2013). Reduction in the quantity of peanut produced contribute to high peanut prices which is a major constraint in the downstream phase of the chain. Quality loss include those that affect the edibility, acceptability, income, and nutrient composition. This is a common phenomenon in developed countries (Kader, 2002). Peanut contaminated with aflatoxin affects the quality of the peanut and reduce its acceptability and edibility, thus leading to price discounting and economic loss due to low acceptability by both traders and consumers within the peanut value chain (Hodges et al., 2011; Kader, 2005). 
The framework shows that poor production practices (poor land preparation, use of recycled and susceptible seed variety, wrong plant population, insect, and pest management), abiotic (terminal drought), delayed harvest, improper drying method, and poor transportation and storage can increase the probability of the peanut being contaminated with aflatoxin. These challenges increase both the quantity and quality of loss. Within the value chain, quality of the peanut may further be reduced as farmers sell the contaminated peanut to other actors within the chain. The consequence of this action is more detrimental to the end-users of the peanut. A reduction in quality of the peanut leads to price discounting while reduction in quantity increases the price of peanut given that the quality is not compromised. Lack of innovations available to wholesalers, processors, and retailers may further increase the probability of the peanut being contaminated with aflatoxin.

[Figure 3]

Several methods and innovations such as use of resistant varieties, cultivating under irrigation, early harvesting, proper drying, sorting, proper storage, good processing methods, pest management, and education can be used to reduce the loss at the farmer level. However, each of the innovations is associated with a specific cost structure. High postharvest losses associated with peanut production requires an innovation that can reduce the losses significantly and increase the economic returns. This study emphasize the use of farmer-led improved storage structure and the underlying factors influencing adoption. The improved storage technique is adopted if the expected profit from using the innovation is higher than using the status quo. We assume that farmers in our sample are rational and will use the improved storage technique so long as the technology is affordable and information regarding its management is readily available.

\subsection{Theoretical framework}


Adoption of new technologies among subsistence farmers vary with the socio-economic characteristics of the farm households given that the objective of the household decision maker is to increase production to meet household food requirements (Sadoulet and de Janvry, 1995). Farm households are assumed to maximize their welfare by investing in technologies (improved storage structure) with higher expected benefit relative to the traditional methods. Following the argument of de Janvry et al. (2010), heterogeneous agents make optimizing decision on the adoption and input use subject to their budget constraints, information, credit, risk and uncertainties and the availability of the technology and their complement inputs. The anticipated benefit from an improved technology usually influence the extent of investment in the technology taking into consideration the resource constraints common to farm households in SSA.

Technology adoption is modelled within the random utility framework where decision to adopt is considered as a choice and not treatment. Farm households will choose a technology if and only if the technology is profitable relative to other options. However, the decision can be discrete (whether or not to adopt the technology) or continuous (extent of use of the technology). Following Khonje et al. (2015), and Ali and Abdulai (2010), the difference (represented as $T^{*}$ ) between the utility from adoption $\left(U_{A i}\right)$ and the utility from non-adoption $\left(U_{N i}\right)$ of improved storage is such that a utility-maximizing farm household $i$, will choose to adopt improved storage structure if $T^{*}=U_{A i}-U_{N i}>0$. Given that the two utilities are unobservable, they can be expressed as a function of observable elements in the following latent variable $\left(T_{i}^{*}\right)$ model:

$$
T_{i}^{*}=X_{i}^{\prime} \beta+\varepsilon_{i} \text { with } T_{i}= \begin{cases}0 & \text { if } T_{i}^{*}>0 \\ 1 & \text { otherwise }\end{cases}
$$


where $T$ is a binary indicator variable that equals 1 if the farmer use improved storage technique and zero otherwise; $\beta$ is a vector of parameters to be estimated; $X$ is a vector of explanatory variables; and $\varepsilon$ is the error term.

Given that farmers are risk averse and using the improve storage structure is knowledge-intensive, we expect farmers to initially experiment with the technology and subsequently adopt and upscale (Sadoulet and De Janvry, 1995). Adoption decision is modeled as two separate or related processes (Ghimire and Huang, 2015; Liverpool-Tasie, 2014; Noltze et al., 2012). The discrete decision to adopt improved storage structure is modelled as one process and the decision on the quantity of peanut that is stored in the improved structure is also estimated as a separate or conditional model (Zhou et al., 2010). The Tobit model is used when the two decisions are jointly made (Greene, 1993) while the double hurdle (DH) model is used if the two decisions are made separately (Cragg, 1971). In the DH model, a probit model is estimated in the first stage and then a conditional truncated model is estimated in the second stage.

\subsection{Empirical model}

The choice of a specific empirical model depends on the separability and selectivity bias test. The separability in adoption decision is based on a restriction test which uses the log likelihood values obtained from separate estimation of a probit, truncated and Tobit regression models (Mal et al., 2012) as specified in equations (2), (3), and (4) respectively.

$$
\begin{gathered}
Y=\operatorname{Prob}\left(Y \mid Y^{*}>0\right)=X \vartheta+\varepsilon \\
Z=E\left(Z \mid Z^{*}>0\right)=X \beta+\mu \\
M=(X \vartheta+\varepsilon)+(X \beta+\mu)=X(\vartheta+\beta)+\varepsilon+\mu=X \gamma+\varphi
\end{gathered}
$$


Equation (2) explains the adoption decision where $Y$ represent the adoption state, $Y^{*}$ is the latent adoption state, $X$ is vector of explanatory variables, $\vartheta$ vector of coefficients of the explanatory variables and $\varepsilon$ the error term. Equation (3) explains the intensity of adoption where $Z$ is the number of seasons when peanut was stored using the improved storage structure, $Z^{*}$ is the latent intensity state and conditional on the adoption decision, $\beta$ is vector of coefficients of the explanatory variables and $\mu$ the error term. Equation (4) combines the first two decisions in a single model. The coefficient $\gamma$ jointly captures the probability and intensity of use of improved storage structure and $\varphi$ is the error term.

Following Mabuza, Ortmann, and Wale (2014), the best choice model is based on a likelihood ratio test to compare the double hurdle model with the Tobit model as follows:

$$
\lambda=2\left(L L_{\text {Probit }}+L L_{\text {Truncreg }}-L L_{\text {Tobit }}\right)
$$

where $L L_{\text {Probit }}$ is the log-likelihood of the probit, $L L_{\text {Truncreg }}$ is the log-likelihood of the truncated model, and $L L_{\text {Tobit }}$ is the log-likelihood of the Tobit model. The test statistic has a chi-square distribution with degrees of freedom equal to the number of coefficients (including the intercept). The Tobit model is rejected in favor of the two-step model if $\lambda$ exceeds the appropriate chi-square critical value (Burke, 2009). Our results ${ }^{2}$ suggest the data is best fitted to the double hurdle model compared to the Tobit model (Table A2).

Joint estimation of equations (2) and (3) is referred to as the Cragg model. According to Burke (2009), the Cragg model is specified by the following equation:

\footnotetext{
${ }^{2}$ Tobit model was rejected in favor of the double-hurdle model because the computed lambda $(\lambda)$ from the likelihood ratios (549.768) exceeded the critical $\mathrm{chi}^{2}$ value. Decision and intensity of adoption were separately analyzed.
} 


$$
f\left(w, y \mid x_{1}, x_{2}\right)=\left\{1-\Phi\left(x_{1}, \gamma\right)\right\}^{1(w=0)}\left[\Phi\left(x_{1}, \gamma\right)(2 \pi)^{\frac{1}{2}} \sigma^{-1} \exp \left\{\frac{-\left(y-x_{2} \beta\right)^{2}}{2 \sigma^{2}}\right\} / \Phi\left(\frac{x_{2} \beta}{\sigma}\right)^{1(w=1)}\right]
$$

where $w$ is the binary indicator equal to 1 if $\mathrm{y}$ is positive and 0 otherwise, $y$ is previously defined, $x_{1}, x_{2}$ are sets of explanatory variables determining $w$ and $y$. The average partial effects (APEs) ${ }^{3}$ were estimated since the coefficients of the double hurdle is not straight forward. Explanation and derivation of the methods of computing APEs are detailed in Burke (2009).

In order to test for selectivity bias in the adoption decisions, the Heckman two stage model is employed. Computation of inverse mills ratio (IMR) from the probit model (specified in equation 2) serves as the first stage of the Heckman model. The second stage of the model is estimated as follows:

$$
D=E\left(d \mid d^{*}>0\right)=X \psi+\lambda(X \vartheta)+\eta
$$

where $\lambda(X \vartheta)$ is the IMR which corrects for the selectivity bias in the truncated regression model (equation 3) and $\eta$ is the error term. According to Marchenko and Marc (2012), the intensity of adoption depends on the discrete decision to adopt given that the IMR is significant. Therefore, Heckman is more appropriate relative to the Cragg's model. Conversely, the Cragg's model is more applicable in the absence of selectivity bias based on the insignificance of the IMR. Our results from the selectivity test suggest no selectivity bias in the choice of improved storage structure (Table A3), therefore our analysis focuses on the Cragg's model.

\footnotetext{
${ }^{3}$ The APEs were computed using the margins command in STATA and the associated standard errors and the $P$ values were computed using the delta method.
} 


\subsection{Description of variables used in the models}

The variables used in the models were selected based on the adoption literature. These variables ranges from demographic, farm-level, institutional and technology specific (Varma, 2017; Khonje et al., 2015; Manda, Alene, Gardebroek, Kassie \& Tembo, 2016). To capture the effect of human capital and demography on the adoption of improved storage, we include age, gender, education, and household size. Probability of adopting improved storage structure is expected to be higher for men than women due to credit constraints faced by women (Pender \& Gebremedhin, 2007). In northern Ghana, women have limited access to the financial markets, land, and extension services. Age is hypothesized to have both positive (Kassie et al., 2013) and negative (Manda et al., 2015) effect on adoption. Older farmers are more experienced and may have accumulated more social and physical capital that enhances adoption of improved technologies. Alternatively, younger farmers may be more innovative and willing to experiment with new technologies (Asfaw et al., 2012; Adesina \& Zinnah, 1993). Education is expected to increase the probability of adopting improved storage structure (Khonje et al., 2015; Moser \& Barret, 2013; Langyintuo \& Mungoma, 2008). Education enhance the ability of farmers to process and make informed decision much faster than less educated farmers make.

Household size captures labor endowment of farm households since construction and maintaining of the storage structure is labor intensive. We include economically active household members to determine their contribution towards investment in improved storage structure. The effect of this variable on adoption of improved storage structure is expected to be both positive and negative. Economically active members of the household may not invest part of their income in agricultural activities and also reduce the household labor supply. On the contrary, these household members 
may contribute towards investment in improved technologies that are economically more rewarding but relatively expensive.

Institutional factors such as access to extension and membership of farmer association are included to capture the effect of information and awareness of existing improved technologies and their effect on adoption behavior of farmers. Access to extension increases the probability of adopting improved technologies (Khonje et al., 2015; Manda et al., 2016; Asfaw et al., 2012). Membership of association provides farmers the opportunity to share information and learn from fellow farmers (Conley and Udry, 2010).

Farm level and post-production characteristics such as cropping system, quantity of peanut produced, quantity affected by aflatoxin, crop rotation, previous storage problem, and drying of peanut are expected to capture processes that leads to peanut contamination, thus the need to adopt strategies such as improved storage structure. Farmers who are aware of aflatoxin are more likely to take preventive measures relative to those that are not informed. We included a location dummy to capture production, market and institutional heterogeneity across the study areas. Table A1 describes the variables and their expected signs.

\section{Results and discussion}

\subsection{Determinants of adoption and intensity of use of improved storage structure}

Factors influencing the decisions to adoption and extent of use of improved storage structure are separately determined. Risk-averse farmers make adoption decisions based on the information available. These beliefs are update depending on the accuracy of the information and the ability to 
implement the information and how rewarding the decision tend to be (Sadoulet and De Janvry, 1995).

Adoption of farmer-led improved storage structure (first hurdle) is significantly determined by sex, economic active household members, marital status, early harvesting of peanut, cleaning of pod after drying, storing of peanut in other places relative to the field, awareness of aflatoxin control, and location of farmer residence. The intensity (second hurdle) of using improved storage structure is significantly influenced by household size, economic active household members, storing of peanut in other places relative to the field, quantity of peanut affected by aflatoxin, purchase of peanut from processors, and location of farmer residence (Table 6). Since the magnitude of the estimates in the Cragg model cannot be directly interpreted, we estimated the average partial effect using the coefficient of the model.

Male farmers are more likely to use improved storage structure. The extent of storing peanut in improved storage structure is 0.165 higher for males relative to females. This confirms the problem of wide gender inequality in northern Ghana. Women are often constrained in the adoption of new technologies due to lack of funds and control over productive resources (Deere and Leon, 2014), access to capital (Fletschner, 2008; Fletschner, 2009), and the type of off-farm activities they can engage in given their roles and social norms (Fletschner and Carter, 2008; Kevane, 2004). The adoption of improved storage structure is associated with relatively high amount of initial capital investment and recurrent cost which is an encumbrance for most female farmers. Most of these female farmers are credit constrained and may not have the collateral to guarantee credit 
advancement. Policies that improve women's access to production, post-harvest technologies, and credit must be encouraged.

An additional unit of household members increases the intensity of using improved storage structure by about 0.15 . The result is consistent with the a priori expectation. This suggests that as household size increases, improved storage structure is more likely to be used for a longer period of time. Groundnut production and post-production systems are labor-intensive. Construction of improved storage structure and its maintenance require both capital and labor. The labor constraint is relaxed with increase in household size that serves as family labor for agricultural activities. Given the importance of household members in the agricultural sector, training programs must include household members directly involved in farming decisions.

The result shows that an additional unit of economic active household members decrease the intensity of improved storage structure use by about 0.27 . A positive relationship is usually expected if households who are gainfully employed contributes towards the total cost of household production. However, the inverse relationship could be due to partial autonomy of economic active household members thus reducing their contribution towards the household agricultural production. It is likely that these unit may be supporting other household members in terms of their schooling, vocational training, and trading. In view of this, improvement in the local economy will enable farm households to participate in off-farm activities to generate enough funds to support the agricultural activities within the household while the economically active household members financially support other non-farm activities. 
Marital status substantially reduces the intensity of using improved storage structure. The intensity of using improved storage structure by married farmers was 1.92 lower than single farmers. Considering that married households are more likely to jointly allocate their resources more efficiently, we expect marital status to have a positive effect on the use of improved storage structure. However, it is a common practice in northern Ghana for husband to control most of the production resources, income from sales of crop, and decide on the type of investment to make. According to Hoddinott et al. (1997), spouses may hold conflicting interest and may refuse to share information, labor and assets. In such circumstances, husbands may be reluctant to reduce the gender-specific constraints of their spouse in the financial market despite having adequate access to capital (Fletschner, 2008). Development programs based on commercial development of farm households must encourage collective household bargaining among spouse to enhance effective utilization of joint resource for improved welfare.

Cleaning of the pod after harvest is associated with a substantial increase in the intensity of using storage structure. The intensity of using improved storage structure by farmers who clean the pod after harvest was found to be 2.44 higher than that of farmers who do not clean the pod after harvest. The probability of infesting the peanut with aflatoxin during storage is very high especially when farmers pay less attention to both agronomic and post-production activities such as cleaning of the pod. Peanut contaminated with aflatoxin from the field are more likely to be transferred into the storage structure. Nevertheless, farmers who allocate part of their time in cleaning the pods after harvesting are more likely to use improved storage structure to ensure that the quality of the peanuts are not compromised. There is the need to emphasize cleaning of the pods in the postharvest training programs organized by development organizations. 
The intensity of using improved storage structure is 3.14 higher for farmers who reside in the Northern Region of Ghana relative to those who reside in Upper East and Upper West regions. The agro-ecological zone accounts for the use and profitability of technologies (Doris and Morris, 2001). Crop technologies related to peanut production performs well in the three Northern regions of Ghana. The Northern Region contributes largely to the national peanut production relative to Upper East and Upper West regions (Angelucci and Bazzucchi, 2013). Peanut farmers in Northern Region are more likely to adopt technologies such as improved storage technique given the volume of peanut produced annually and the continuous support received from development organizations. Secondly, the opportunity cost of damage is very high with substantial volume of peanut production thus farmers are highly motivated to use improved storage structure. Price of peanut is usually low in the production regions and during the harvesting period, therefore farmers are more likely to sell few of their produce to overcome the high cost of storage. Consequently, farmers may store the peanut for a relatively long period in anticipation of future high price. A study by Simtowe et al. (2010) showed that the location of a farmer influence the adoption of improved groundnut varieties in Malawi. The result suggests that farmers in the Upper Regions of Ghana must be targeted, trained, and supported financially to enhance their uptake of improved storage structure to reduce aflatoxin contamination and enhance food security.

[Table 6]

\section{Conclusion}

Poor agronomic practices, abiotic factors such as terminal drought, and low use of improved storage techniques have exposed peanut to aflatoxin contamination in SSA. Consumption of 
aflatoxin contaminated peanut poses serious threat to the health of both humans and animals. The use of improved storage technique has been identified as a major intervention to reduce the rate of peanut contamination. However, understanding the socio-economic factors, farming system, postharvest practices, and location of farmers will enable development practitioners to develop effective strategies for the promotion of this technology. This paper identifies the factors influencing the probability and intensity of using improved groundnut storage structure.

Generally, most of the peanut producers are aware of aflatoxin but lack knowledge on control measures therefore leading to huge losses which is a serious threat to household income and consumer safety. We observe a statistical significant difference between farmers who are aware and unaware of aflatoxin in terms of the production volume of peanut and quantity contaminated with aflatoxin. Adopters of improved storage structure within the fifth quintile of peanut production have lower quantity of peanut contaminated with aflatoxin compared to non-adopters. The quantity of peanut contaminated with aflatoxin increases with production.

The probability of adopting improved storage structure is significantly determined by sex, economic active household members, marital status, early harvesting of peanut, cleaning of pod after drying, storing of peanut in other places relative to the field, awareness of aflatoxin control, and location of farmer residence. Secondly, the intensity of using improved storage structure is significantly influenced by household size, economic active household members, storing of peanut in other places relative to the field, quantity of peanut affected by aflatoxin, purchase of peanut from processors, and location of farmer residence. The implication of the results suggest the need for continuous education of farmers and effective campaigns by development practitioners in 
promoting the farmer-led improved storage structure. Training programs designed by research institutions in partnership with agricultural extension agents (AEAs) should incorporate both good agronomic practices and storage treatment methods. These strategies will help mitigate the harmful effect of aflatoxin and also reduce the risk of losses. Programs that enhance women access to agricultural technologies and innovations must be vigorously pursued. Despite the insight gained from this study, future studies must analyzed the profitability of using different combinations of production and post-harvest practices and their impact on household welfare.

\section{References}

Achaglinkame, M. A., Opoku, N., \& Amagloh, F. K. (2017). Aflatoxin contamination in cereals and legumes to reconsider usage as complementary food ingredients for Ghanaian infants: A review. Journal of Nutrition \& Intermediary Metabolism. 10, 1-7.

Adesina, A. A., \& Zinnah, M. M. (1993). Technology characteristics, farmers' perceptions and adoption decisions: A Tobit model application in Sierra Leone. Agricultural Economics. 9(4), 297311. doi:10.1016/ 0169-5150(93)90019-9

Ali, A., \& Abdulai, A. (2010). The adoption of genetically modified cotton and poverty reduction in Pakistan. Journal of Agricultural Economics, 61(1), 175-192.

Angelucci F., Bazzucchi A., 2013. Analysis of incentives and disincentives for peanuts in Ghana. Technical notes series, MAFAP, FAO, Rome.

Annigan, J., (2014). Healthy Eating: The Effects of Low Protein Intake. SFgate. Available at: http:// healthyeating.sfgate.com/effects-low-protein-intake-7123.html.

Asfaw, S., Shiferaw, B., Simtowe, F., \& Lipper, L. (2012). Impact of modern agricultural technologies on smallholder welfare: Evidence from Tanzania and Ethiopia. Food policy, 37(3), 283-295.

Atehnkeng, J., Ojiambo, P. S., Donner, M., Ikotun, T., Sikora, R. A., Cotty, P. J., \& Bandyopadhyay, R. (2008). Distribution and toxigenicity of Aspergillus species isolated from maize kernels from three agro-ecological zones in Nigeria. International Journal of food microbiology, 122(1-2), 74-84.

Bankole, S., Schollenbeger, M., \& Drochner, W. (2006). Mycotoxin contamination in food systems in sub-saharan Africa. Bydgoszcz: Society for Mycotoxin Research, 37.

Burke, W. J. (2009). Fitting and interpreting Cragg's tobit alternative using Stata. Stata Journal, 9(4), 584. 
Conley, T. G., \& Udry, C. R. (2010). Learning about a new technology: Pineapple in Ghana. American economic review, 100(1), 35-69.

Cragg, J. G. (1971). Some statistical models for limited dependent variables with application to the demand for durable goods. Econometrica: Journal of the Econometric Society, 829-844.

DAI. 2014. Peanut Market Diagnostics. DFID Market Development (MADE) in Northern Ghana Program Report submitted to Department for International Development, Ghana.

http://ghana-made.org/wp-content/uploads/2015/11/Peanut-Diagnostics.pdf

de Janvery, A., Dustan, A., Sadoulet, E. (2010). Recent advances in impact analysis methods for ex-post impact assessments of agricultural technology: options for the CGIAR. Paper prepared for the workshop "Increasing the rigor of ex-post impact assessment of agricultural research: a discussion on estimating treatment effects", the CGIAR Standing Panel on Impact Assessment, SPIA, October 2, 2010, Berkeley.

Doss, C. R., \& Morris, M. L. (2001). How does gender affect the adoption of agricultural innovations?: The case of improved maize technology in Ghana. Agricultural Economics, 25(1), 27-39.

European Commission-EC. (2007). Commission Regulation (EC) No. 1126/2007 of 28 September 2007 amending Regulation (EC) No. 1881/2006 setting maximum levels for certain contaminants in foodstuffs as regards Fusarium toxins in maize and maize products. Official Journal of European Union. L 255/14.

Fletschner, D. (2009). Rural women's access to credit: market imperfections and intrahousehold dynamics. World Development, 37(3), 618-631.

Fletschner, D. (2008). Women's access to credit: does it matter for household efficiency? American Journal of Agricultural Economics, 90(3), 669-683.

Fletschner, D., \& Carter, M. R. (2008). Constructing and reconstructing gender: Reference group effects and women's demand for entrepreneurial capital. The Journal of Socio-Economics, 37(2), 672-693.

Fletcher, S. M., \& Shi, Z. (2016). An overview of world peanut markets. In Peanuts (pp. 267-287).

Gage, D., Bangnikon, J., Abeka-Afari, H., Hanif, C., Addaquay, J., Antwi, V. and Hale, A., 2012. The market for maize, rice, soy, and warehousing in Northern Ghana. This report was produced by USAID's Enabling Agricultural Trade (EAT) Project.

Ghana Statistical Service, GLSS. 2012. “2010 Population \& Housing Census”. Accra, Ghana

Ghimire, R., \& Huang, W. C. (2015). Household wealth and adoption of improved maize varieties in Nepal: a double-hurdle approach. Food Security, 7(6), 1321-1335. 
Greene, W.H., (1993). Econometric Analysis, Macmillan. New York.

Hoddinott, J., Alderman, H., \& Haddad, L. (1997). Testing competing models of intrahousehold allocation. Intrahousehold resource allocation in developing countries, 129-41.

Hodges, R. J., Buzby, J. C., \& Bennett, B. (2011). Postharvest losses and waste in developed and less developed countries: Opportunities to improve resource use. Journal of Agricultural Science, 149(S1), 37-45.

Kaaya, A. N., Harris, C., \& Eigel, W. (2006). Peanut aflatoxin levels on farms and in markets of Uganda. Peanut Science, 33(1), 68-75.

Kader, A.A. (2002). Postharvest technology of horticultural crops. 3rd Ed. University of California Agriculture and Natural Resources, Oakland, Publ. 3311.

Kader, A. A. (2005). Increasing food availability by reducing postharvest losses of fresh produce. Acta Horticulturae (ISHS), 682, 2169-2176.

Kassie, M., Jaleta, M., Shiferaw, B., Mmbando, F., \& Mekuria, M. (2013). Adoption of interrelated sustainable agricultural practices in smallholder systems: Evidence from rural Tanzania. Technological forecasting and social change, 80(3), 525-540.

Kevane, M. (2004). Women and development in Africa: How gender works. Lynne Rienner Publishers.

Khonje, M., Manda, J., Alene, A. D., \& Kassie, M. (2015). Analysis of adoption and impacts of improved maize varieties in eastern Zambia. World Development, 66, 695-706. doi:10.1016/j.worlddev.2014.09.008

Kitinoja, L., \& Gorny, J. R. (2013). Postharvest technology for small-scale produce marketers: economic opportunities, quality and food safety. University of California, Davis, CA.

Langyintuo, A. S., \& Mungoma, C. (2008). The effect of household wealth on the adoption of improved maize varieties in Zambia. Food Policy. 33(6), 550-559. doi:10.1016/j.foodpol.2008.04.002

Liverpool-Tasie, L. S. O. (2014). Fertilizer subsidies and private market participation: the case of Kano State, Nigeria. Agricultural Economics, 45(6), 663-678.

Mabuza, M. L., Ortmann, G., \& Wale, E. (2014). Effects of transaction costs on mushroom producers' choice of marketing channels: implications for access to agricultural markets in Swaziland. South African Journal of Economic and Management Sciences, 17(2), 01-13.

Mal, P., Anik, A. R., Bauer, S., \& Schmitz, P. M. (2012). Bt Cotton Adoption: A Double-hurdle Approach for North Indian Farmers. AgBioForum, 15(3), 294-302. 
Manda, J., Alene, A.D., Gardebroek, C., Kassie, M. and Tembo, G. (2016). Adoption and impacts of sustainable agricultural practices on maize yields and incomes: evidence from Rural Zambia. Journal of Agricultural Economics, 67(1), pp.130-153.

Marchenko, Y. V., \& Genton, M. G. (2012). A Heckman selection-t model. Journal of the American Statistical Association, 107(497), 304-317.

Moser, C. M., \& Barrett, C. B. (2003). The disappointing adoption dynamics of a yield-increasing, low external input technology: The case of SRI in Madagascar. Agricultural Systems. 76(3), 10851100. doi:10.1016/ S0308-521X(02)00041-0

Mutegi, C. K., Wagacha, J. M., Christie, M. E., Kimani, J., \& Karanja, L. (2013). Effect of storage conditions on quality and aflatoxin contamination of peanuts (Arachis hypogaea L.). International Journal of AgriScience, 3(10), 746-758.

Noltze, M., Schwarze, S., \& Qaim, M. (2012). Understanding the adoption of system technologies in smallholder agriculture: The system of rice intensification (SRI) in Timor Leste. Agricultural systems, 108, 64-73.

Owusu, K. (2018). Rainfall changes in the savannah zone of northern Ghana 19612010. Weather, 73(2), 46-50.

Pankaj, S. K., Shi, H., \& Keener, K. M. (2018). A review of novel physical and chemical decontamination technologies for aflatoxin in food. Trends in Food Science \& Technology, 71, 7383

Pazderka, C., \& Emmott, A. (2010). Chatham House Procurement for Development Forum: Groundnuts Case Study. Chatham House.

Pender, J., \& Gebremedhin, B. (2007). Determinants of agricultural and land management practices and impacts on crop production and household income in the highlands of Tigray, Ethiopia. Journal of African Economies, 17(3), 395-450.

Sadoulet, E. and de Janvry, A. (1995). Quantitative Development Policy Analysis. Baltimore: The Johns Hopkins University Press.

Simtowe, F., Asfaw, S., Diagne, A., \& Shiferaw, B. A. (2010, September). Determinants of Agricultural Technology adoption: the case of improved groundnut varieties in Malawi. In 2010 AAAE Third Conference/AEASA 48th Conference, September 19-23, 2010, Cape Town, South Africa (No. 95921). African Association of Agricultural Economists (AAAE) \& Agricultural Economics Association of South Africa (AEASA).

Udomkun, P., Wiredu, A. N., Nagle, M., Müller, J., Vanlauwe, B., \& Bandyopadhyay, R. (2017). Innovative technologies to manage aflatoxins in foods and feeds and the profitability of application-A review. Food control, 76, 127-138. 
Varma, P. (2017). Adoption of System of Rice Intensification under Information Constraints: An Analysis for India. The Journal of Development Studies, pp.1-19.

Wu, F. (2007). Measuring the economic impacts of Fusarium toxins in animal feeds. Animal Feed Science and Technology, 137(3-4), 363-374.

Villa, P., \& Markaki, P. (2009). Aflatoxin B1 and ochratoxin A in breakfast cereals from Athens market: occurrence and risk assessment. Food Control, 20(5), 455-461.

Zhou, Y., Yang, H., Mosler, H. J., \& Abbaspour, K. C. (2010). Factors affecting farmers' decisions on fertilizer use: A case study for the Chaobai watershed in Northern China. Consilience, (4), 80102. 


\section{List of Tables}

Table 1: Definition of variables in the regression and summary statistics

\begin{tabular}{|c|c|c|c|}
\hline Variable & Description & Mean & SD \\
\hline \multicolumn{4}{|l|}{ Dependent variables } \\
\hline Use of improved storage structure & Dummy variable ( $1=$ yes $0=$ otherwise $)$ & 0.423 & 0.495 \\
\hline Number of seasons improved storage used & Continuous variable (number) & 4.571 & 6.151 \\
\hline \multicolumn{4}{|l|}{ Explanatory variables } \\
\hline Age & Continuous variable (years) & 40.323 & 10.077 \\
\hline Sex & Dummy variable $(1=$ male $0=$ female $)$ & 0.752 & 0.432 \\
\hline Years of schooling & Continuous variable (years) & 3.712 & 5.659 \\
\hline Household size & Continuous variable (number) & 11.050 & 7.126 \\
\hline Economic active household members & Continuous variable (number) & 5.226 & 4.409 \\
\hline Marital status & Dummy variable ( $1=$ married $0=$ otherwise $)$ & 0.871 & 0.335 \\
\hline Practice crop rotation & Dummy variable ( $1=$ yes $0=$ otherwise $)$ & 0.718 & 0.451 \\
\hline Total groundnut produced & Continuous variable (kilogram) & 795.120 & 934.936 \\
\hline Early harvesting of peanut & Dummy variable ( $1=$ yes $0=$ otherwise $)$ & 0.865 & 0.342 \\
\hline Total groundnut affected by aflatoxin & Continuous variable (kilogram) & 40.661 & 79.808 \\
\hline Total days for harvesting peanut & Continuous variable (number) & 4.716 & 3.437 \\
\hline Awareness of aflatoxin control & Dummy variable ( $1=$ yes $0=$ otherwise) & 0.323 & 0.468 \\
\hline Practice intercropping & Dummy variable ( $1=$ yes $0=$ otherwise $)$ & 0.661 & 0.474 \\
\hline Clean peanut pod after drying & Dummy variable ( $1=$ yes $0=$ otherwise $)$ & 0.627 & 0.484 \\
\hline Timing of peanut harvest on the field & $\begin{array}{l}\text { Dummy variable ( } 1=\text { with interruption and } \\
0=\text { otherwise) }\end{array}$ & 0.674 & 0.469 \\
\hline Days of drying the pod & Continuous variable (number) & 6.643 & 3.592 \\
\hline Purchase peanut from processors & Dummy variable ( $1=$ yes $0=$ otherwise $)$ & 0.708 & 0.455 \\
\hline Awareness of aflatoxin & Dummy variable ( $1=$ yes $0=$ otherwise $)$ & 0.665 & 0.473 \\
\hline Store peanut in the courtyard & Dummy variable ( $1=$ yes $0=$ otherwise $)$ & 0.627 & 0.484 \\
\hline Store peanut besides the house & Dummy variable ( $1=$ yes $0=$ otherwise $)$ & 0.310 & 0.463 \\
\hline Store peanut in other place & Dummy variable ( $1=$ yes $0=$ otherwise) & 0.053 & 0.225 \\
\hline Reside in Northern Region & Dummy variable ( $1=$ yes $0=$ otherwise $)$ & 0.373 & 0.484 \\
\hline Reside in Upper East Region & Dummy variable ( $1=$ yes $0=$ otherwise $)$ & 0.313 & 0.465 \\
\hline
\end{tabular}

Notes: SD refers to standard deviation

Table 2: Difference in production and contaminated peanut by awareness of aflatoxin

\begin{tabular}{|c|c|c|c|}
\hline & $\begin{array}{c}\text { Awareness of } \\
\text { aflatoxin }\end{array}$ & $\begin{array}{c}\text { Unaware of } \\
\text { aflatoxin }\end{array}$ & Difference \\
\hline & $\begin{array}{c}\text { Mean } \\
\text { (Std. dev) }\end{array}$ & $\begin{array}{c}\text { Mean } \\
\text { (Std. dev) }\end{array}$ & $\begin{array}{c}\text { Mean } \\
\text { (Std. dev) }\end{array}$ \\
\hline Total production $(\mathrm{kg})$ & $\begin{array}{l}923.44 \\
(73.15)\end{array}$ & $\begin{array}{l}540.87 \\
(49.87)\end{array}$ & $\begin{array}{c}-382.57 * * * \\
(108.95)\end{array}$ \\
\hline
\end{tabular}


Production volume affected by aflatoxin $(\mathrm{kg})$

51.33

19.52

$-31.82 * * *$

(6.37)

(3.48)

(9.31)

Notes: The difference is computed as the mean of awareness group minus mean of unaware group. Std. dev. refers to standard deviation.

Table 3: Difference in production and contaminated peanut by awareness of aflatoxin control

\begin{tabular}{|c|c|c|c|}
\hline & $\begin{array}{c}\text { Awareness of } \\
\text { aflatoxin control }\end{array}$ & $\begin{array}{c}\text { Unaware of } \\
\text { aflatoxin control }\end{array}$ & Difference \\
\hline & $\begin{array}{c}\text { Mean } \\
\text { (Std. dev) }\end{array}$ & $\begin{array}{c}\text { Mean } \\
\text { (Std. dev) }\end{array}$ & $\begin{array}{c}\text { Mean } \\
\text { (Std. dev) }\end{array}$ \\
\hline Total production $(\mathrm{kg})$ & $\begin{array}{l}1014.18 \\
(124.25)\end{array}$ & $\begin{array}{l}690.66 \\
(48.33)\end{array}$ & $\begin{array}{c}-323.52 * * * \\
(110.65)\end{array}$ \\
\hline Production volume affected by aflatoxin $(\mathrm{kg})$ & $\begin{array}{l}28.14 \\
(6.88)\end{array}$ & $\begin{array}{l}46.63 \\
(5.69)\end{array}$ & $\begin{array}{l}18.49 * \\
(9.52)\end{array}$ \\
\hline
\end{tabular}

Notes: The difference is computed as the mean of aflatoxin control group minus mean of unaware of aflatoxin group. Std. dev. refers to standard deviation.

Table 4: Household, production and post-production practices by adoption status

\begin{tabular}{lccccccc}
\hline \multirow{2}{*}{ Variables } & \multicolumn{2}{c}{ Non-adopters $(\mathrm{n}=184)$} & & \multicolumn{2}{c}{ Adopters $(\mathrm{n}=135)$} & \\
\cline { 2 - 3 } \cline { 6 - 7 } & Mean & SD & & Mean & SD & \\
\hline Age & 40.413 & 9.743 & & 40.200 & 10.550 & 0.852 \\
Sex & 0.652 & 0.478 & & 0.889 & 0.315 & 0.000 \\
Years of schooling & 3.690 & 5.913 & & 3.741 & 5.317 & 0.937 \\
Household size & 10.103 & 6.500 & & 12.341 & 7.739 & 0.005 \\
Economically active household members & 5.005 & 4.086 & & 5.526 & 4.814 & 0.298 \\
Marital status & 0.902 & 0.298 & & 0.830 & 0.377 & 0.056 \\
Practice crop rotation & 0.674 & 0.470 & & 0.778 & 0.417 & 0.042 \\
Total groundnut produced & 755.180 & 775.121 & & 849.558 & 1117.445 & 0.374 \\
Early harvesting of peanut & 0.842 & 0.365 & & 0.896 & 0.306 & 0.165 \\
Total groundnut affected by aflatoxin & 41.852 & 79.823 & & 39.037 & 80.056 & 0.756 \\
Total days for harvesting peanut & 5.014 & 3.714 & & 4.311 & 2.984 & 0.071 \\
Awareness of aflatoxin control & 0.283 & 0.451 & & 0.378 & 0.487 & 0.073 \\
Practice intercropping & 0.679 & 0.468 & & 0.637 & 0.483 & 0.432 \\
Clean peanut pod after drying & 0.636 & 0.482 & & 0.615 & 0.488 & 0.702 \\
Timing of peanut harvest on the field & 0.668 & 0.472 & & 0.681 & 0.468 & 0.807 \\
Days of drying the pod & 6.826 & 3.570 & & 6.393 & 3.620 & 0.288 \\
Purchase peanut from processors & 0.712 & 0.454 & & 0.704 & 0.458 & 0.873 \\
Awareness of aflatoxin & 0.652 & 0.478 & & 0.681 & 0.468 & 0.585 \\
Store peanut in the courtyard & 0.560 & 0.498 & & 0.719 & 0.451 & 0.004 \\
Store peanut besides the house & 0.342 & 0.476 & & 0.267 & 0.444 & 0.150 \\
Store peanut in other place & 0.087 & 0.283 & & 0.007 & 0.086 & 0.002 \\
Reside in Northern Region & 0.250 & 0.434 & & 0.541 & 0.500 & 0.000 \\
Reside in Upper East Region & 0.418 & 0.495 & & 0.170 & 0.377 & 0.000 \\
\hline
\end{tabular}


Table 5: Quintiles of production and volume contaminated with aflatoxin by adoption status

\begin{tabular}{|c|c|c|c|c|c|}
\hline \multirow{2}{*}{$\begin{array}{l}\text { Production } \\
\text { Quintiles }\end{array}$} & \multirow{2}{*}{$\begin{array}{l}\text { Number of } \\
\text { Observations }\end{array}$} & \multicolumn{2}{|c|}{ Production $(\mathrm{Kg})$} & \multicolumn{2}{|c|}{ Volume affected $(\mathrm{Kg})$} \\
\hline & & Adopters & Non-adopters & Adopters & Non-adopters \\
\hline First & 64 & 95.343 & 100.944 & 9.617 & 9.486 \\
\hline Second & 65 & 265.037 & 265.632 & 27.381 & 23.945 \\
\hline Third & 68 & 510.179 & 550.075 & 38.000 & 30.918 \\
\hline Fourth & 63 & 967.095 & 916.810 & 52.629 & 51.551 \\
\hline Fifth & 59 & 2416.552 & 2163.933 & 71.483 & 102.217 \\
\hline Total & 319 & 849.558 & 755.180 & 39.037 & 41.852 \\
\hline
\end{tabular}


Table 6. Results of Cragg's double hurdle regression model for determinants of improved storage use

\begin{tabular}{|c|c|c|c|c|c|c|c|c|c|}
\hline \multirow{3}{*}{ Variables } & \multirow{2}{*}{\multicolumn{3}{|c|}{$\begin{array}{c}\text { Hurdle } 1 \\
\begin{array}{c}\text { Adoption of improved storage } \\
\text { structure }\end{array}\end{array}$}} & \multirow{2}{*}{\multicolumn{3}{|c|}{$\begin{array}{c}\text { Hurdle } 2 \\
\begin{array}{l}\text { Intensity of use of improved } \\
\text { storage structure }\end{array}\end{array}$}} & \multirow{2}{*}{\multicolumn{3}{|c|}{$\begin{array}{c}\text { Average partial effect } \\
\text { Unconditional expected value } \\
\text { of y }(E[y i \mid x])\end{array}$}} \\
\hline & & & & & & & & & \\
\hline & Coefficient & $\begin{array}{c}\text { Robust } \\
\text { Std. error }\end{array}$ & P vale & Coefficient & $\begin{array}{c}\text { Robust } \\
\text { Std. error }\end{array}$ & $\mathrm{P}$ vale & Coefficient & $\begin{array}{l}\text { Bootstrap } \\
\text { Std. error }\end{array}$ & P vale \\
\hline \multicolumn{10}{|l|}{ Farmer demographics } \\
\hline Age & -0.001 & 0.008 & 0.926 & 0.002 & 0.047 & 0.962 & -0.002 & 0.039 & 0.967 \\
\hline Sex & 0.702 & 0.214 & 0.001 & 0.527 & 1.668 & 0.752 & 2.590 & 1.094 & 0.018 \\
\hline Years of schooling & -0.006 & 0.016 & 0.680 & -0.112 & 0.087 & 0.200 & -0.067 & 0.074 & 0.368 \\
\hline Household size & 0.026 & 0.018 & 0.148 & 0.147 & 0.072 & 0.041 & 0.148 & 0.080 & 0.065 \\
\hline Economic active household members & -0.049 & 0.029 & 0.086 & -0.247 & 0.109 & 0.023 & -0.267 & 0.131 & 0.042 \\
\hline Marital status & -0.460 & 0.267 & 0.084 & -0.901 & 1.057 & 0.394 & -1.920 & 0.999 & 0.055 \\
\hline \multicolumn{10}{|l|}{ Farm characteristics } \\
\hline$\overline{\text { Practice crop rotation }}$ & -0.106 & 0.199 & 0.593 & -0.050 & 1.096 & 0.964 & -0.380 & 0.942 & 0.686 \\
\hline Total groundnut produced & 0.000 & 0.000 & 0.175 & 0.000 & 0.000 & 0.317 & 0.000 & 0.000 & 0.333 \\
\hline Early harvesting of peanut & 0.529 & 0.247 & 0.032 & -1.750 & 1.329 & 0.188 & 1.092 & 0.997 & 0.273 \\
\hline Total days for harvesting peanut & -0.018 & 0.028 & 0.522 & -0.223 & 0.154 & 0.149 & -0.151 & 0.128 & 0.238 \\
\hline Practice intercropping & -0.153 & 0.175 & 0.383 & 0.354 & 0.832 & 0.671 & -0.376 & 0.811 & 0.643 \\
\hline Timing of peanut harvest on the field & -0.130 & 0.198 & 0.510 & 0.275 & 0.850 & 0.746 & -0.332 & 0.748 & 0.657 \\
\hline \multicolumn{10}{|l|}{ Postharvest related characteristics } \\
\hline Days of drying the pod & 0.033 & 0.025 & 0.195 & -0.146 & 0.131 & 0.263 & 0.053 & 0.093 & 0.571 \\
\hline Clean peanut pod after drying & 0.555 & 0.185 & 0.003 & 1.405 & 1.173 & 0.231 & 2.441 & 0.916 & 0.008 \\
\hline Store peanut in the courtyard & -0.142 & 1.090 & 0.896 & 2.786 & 2.213 & 0.208 & 0.631 & 4.490 & 0.888 \\
\hline Store peanut besides the house & -0.446 & 1.092 & 0.683 & 3.549 & 2.373 & 0.135 & -0.091 & 4.949 & 0.985 \\
\hline Store peanut in other place & -2.205 & 1.256 & 0.079 & 10.926 & 3.552 & 0.002 & -3.104 & 6.962 & 0.656 \\
\hline Total groundnut affected by aflatoxin & -0.001 & 0.001 & 0.436 & -0.009 & 0.005 & 0.074 & -0.006 & 0.005 & 0.191 \\
\hline Purchase peanut from processors & 0.142 & 0.211 & 0.500 & 2.966 & 0.969 & 0.002 & 1.668 & 0.937 & 0.075 \\
\hline \multicolumn{10}{|l|}{ Aflatoxin awareness and control variables } \\
\hline Awareness of aflatoxin control & 0.516 & 0.238 & 0.030 & -0.641 & 1.087 & 0.555 & 1.491 & 1.002 & 0.137 \\
\hline Awareness of aflatoxin & -0.225 & 0.215 & 0.295 & 0.464 & 0.960 & 0.629 & -0.578 & 0.869 & 0.506 \\
\hline \multicolumn{10}{|l|}{ Location } \\
\hline Reside in Northern Region & 0.785 & 0.266 & 0.003 & 1.193 & 1.203 & 0.321 & 3.136 & 1.116 & 0.005 \\
\hline Reside in Upper East Region & -0.697 & 0.306 & 0.023 & 5.492 & 1.872 & 0.003 & -0.165 & 1.464 & 0.910 \\
\hline Number of observations & 319 & & & & & & & & \\
\hline Wald chi2 (23) & 61.040 & & & & & & & & \\
\hline Prob. > Chi2 & 0.000 & & & & & & & & \\
\hline Log pseudo likelihood & -544.801 & & & & & & & & \\
\hline
\end{tabular}




\section{Appendix}

Table A1. Variables used in the model and expected signs

\begin{tabular}{|c|c|c|}
\hline Variables & Type of variables & Expected sign \\
\hline \multicolumn{3}{|l|}{ Dependent variables } \\
\hline Use of improved storage structure & Dummy variable ( $1=$ yes $0=$ otherwise) & \\
\hline Number of seasons improved storage used & Continuous variable (number) & \\
\hline \multicolumn{3}{|l|}{ Explanatory variables } \\
\hline Age & Continuous variable (years) & $+/-$ \\
\hline Sex & Dummy variable $(1=$ male $0=$ female $)$ & + \\
\hline Years of schooling & Continuous variable (years) & + \\
\hline Household size & Continuous variable (number) & + \\
\hline Economically active household members & Continuous variable (number) & $+/-$ \\
\hline Marital status & $\begin{array}{l}\text { Dummy variable }(1=\text { married } \\
0=\text { otherwise) }\end{array}$ & $+/-$ \\
\hline Practice crop rotation & Dummy variable ( $1=$ yes $0=$ otherwise) & $+/-$ \\
\hline Total groundnut produced & Continuous variable (kilogram) & + \\
\hline Early harvesting of peanut & Dummy variable ( $1=$ yes $0=$ otherwise) & + \\
\hline Total groundnut affected by aflatoxin & Continuous variable (kilogram) & - \\
\hline Total days for harvesting peanut & Continuous variable (number) & - \\
\hline Awareness of aflatoxin control & Dummy variable ( $1=$ yes $0=$ otherwise) & + \\
\hline Practice intercropping & Dummy variable ( $1=$ yes $0=$ otherwise) & $+/-$ \\
\hline Clean peanut pod after drying & Dummy variable ( $1=$ yes $0=$ otherwise) & + \\
\hline Timing of peanut harvest on the field & $\begin{array}{l}\text { Dummy variable ( } 1=\text { immediately and } \\
\text { continuously } 0=\text { otherwise) }\end{array}$ & - \\
\hline Days of drying the pod & Continuous variable (number) & + \\
\hline Purchase peanut from processors & Dummy variable ( $1=$ yes $0=$ otherwise) & + \\
\hline Awareness of aflatoxin & Dummy variable ( $1=$ yes $0=$ otherwise) & + \\
\hline Store peanut in the courtyard & Dummy variable ( $1=$ yes $0=$ otherwise) & - \\
\hline Store peanut besides the house & Dummy variable ( $1=$ yes $0=$ otherwise) & - \\
\hline Store peanut in other place & Dummy variable ( $1=$ yes $0=$ otherwise) & - \\
\hline Reside in Northern Region & Dummy variable ( $1=$ yes $0=$ otherwise) & + \\
\hline Reside in Upper East Region & Dummy variable ( $1=$ yes $0=$ otherwise) & - \\
\hline
\end{tabular}


Table A2: Separability test based on probit, truncated, and tobit models

\begin{tabular}{|c|c|c|c|c|c|c|c|c|c|}
\hline \multirow[b]{2}{*}{ Variables } & \multicolumn{3}{|c|}{ Probit } & \multicolumn{3}{|c|}{ Truncated } & \multicolumn{3}{|c|}{ Tobit } \\
\hline & Coefficient & $\begin{array}{l}\text { Robust } \\
\text { Std. Err. }\end{array}$ & $P$-value & Coefficient & $\begin{array}{l}\text { Robust } \\
\text { Std. Err. }\end{array}$ & $P$-value & Coefficient & $\begin{array}{l}\text { Robust } \\
\text { Std. Err. }\end{array}$ & $P$-value \\
\hline Age & -0.003 & 0.010 & 0.747 & -0.050 & 0.055 & 0.361 & -0.003 & 0.007 & 0.619 \\
\hline Sex & 0.726 & 0.218 & 0.001 & -0.044 & 1.723 & 0.980 & 0.560 & 0.173 & 0.001 \\
\hline Years of schooling & 0.002 & 0.016 & 0.882 & -0.063 & 0.089 & 0.481 & 0.003 & 0.012 & 0.792 \\
\hline Household size & 0.029 & 0.020 & 0.142 & 0.086 & 0.088 & 0.326 & 0.022 & 0.013 & 0.094 \\
\hline Educated household members & -0.020 & 0.030 & 0.512 & 0.096 & 0.143 & 0.501 & -0.015 & 0.019 & 0.422 \\
\hline Economic active household members & -0.041 & 0.031 & 0.181 & -0.192 & 0.119 & 0.107 & -0.033 & 0.021 & 0.120 \\
\hline Experience in trading & -0.002 & 0.011 & 0.846 & 0.081 & 0.060 & 0.178 & 0.001 & 0.008 & 0.910 \\
\hline Practice crop rotation & -0.114 & 0.198 & 0.565 & 0.452 & 1.126 & 0.688 & -0.094 & 0.150 & 0.530 \\
\hline Total groundnut produced & 0.000 & 0.000 & 0.192 & 0.000 & 0.000 & 0.389 & 0.000 & 0.000 & 0.234 \\
\hline Early harvesting of peanut & 0.516 & 0.243 & 0.034 & -1.501 & 1.211 & 0.215 & 0.378 & 0.185 & 0.042 \\
\hline Total groundnut affected by aflatoxin & -0.001 & 0.001 & 0.433 & -0.007 & 0.005 & 0.181 & -0.001 & 0.001 & 0.490 \\
\hline Total days for harvesting peanut & -0.025 & 0.028 & 0.372 & -0.252 & 0.147 & 0.087 & -0.016 & 0.022 & 0.469 \\
\hline Awareness of aflatoxin control & 0.481 & 0.250 & 0.054 & -0.705 & 1.076 & 0.513 & 0.311 & 0.177 & 0.080 \\
\hline Practice intercropping & -0.147 & 0.173 & 0.397 & 0.324 & 0.819 & 0.692 & -0.094 & 0.119 & 0.432 \\
\hline Total days for drying peanut & 0.003 & 0.034 & 0.937 & 0.125 & 0.144 & 0.385 & 0.008 & 0.026 & 0.766 \\
\hline Cleaning of pods & 0.557 & 0.183 & 0.002 & 1.588 & 1.180 & 0.178 & 0.434 & 0.125 & 0.001 \\
\hline Time for harvesting peanut & 0.182 & 0.197 & 0.355 & -0.146 & 0.801 & 0.855 & 0.129 & 0.137 & 0.347 \\
\hline Number of days peanut is well dried & 0.037 & 0.029 & 0.203 & -0.121 & 0.125 & 0.332 & 0.031 & 0.021 & 0.146 \\
\hline Purchase peanut from processors & 0.124 & 0.210 & 0.554 & 2.884 & 0.957 & 0.003 & 0.103 & 0.152 & 0.498 \\
\hline $\begin{array}{l}\text { Awareness of aflatoxin } \\
\text { Location of storage }\end{array}$ & -0.233 & 0.220 & 0.290 & 0.306 & 1.022 & 0.765 & -0.150 & 0.162 & 0.354 \\
\hline \#Beside the house & -0.342 & 0.204 & 0.094 & 1.097 & 1.101 & 0.319 & -0.237 & 0.154 & 0.125 \\
\hline \#Field & 0.052 & 1.052 & 0.961 & -2.453 & 2.291 & 0.284 & 0.155 & 0.917 & 0.866 \\
\hline $\begin{array}{c}\text { \#Other } \\
\text { Region dummies }\end{array}$ & -2.082 & $\begin{array}{l}0.614 \\
\text { Yes }\end{array}$ & 0.001 & 7.188 & $\begin{array}{l}2.174 \\
\text { Yes }\end{array}$ & 0.001 & -1.653 & $\begin{array}{l}0.498 \\
\text { Yes }\end{array}$ & 0.001 \\
\hline $\begin{array}{l}\text { Constant } \\
\text { Number of observations }\end{array}$ & $\begin{array}{c}-0.728 \\
319\end{array}$ & 0.649 & 0.262 & $\begin{array}{l}9.978 \\
135\end{array}$ & 3.560 & 0.005 & $\begin{array}{c}-0.518 \\
319\end{array}$ & 0.487 & 0.288 \\
\hline Log pseudo likelihood & -170.461 & & & -374.210 & & & -269.787 & & \\
\hline LR test statistics $(\lambda)$ & & & & & $768 * * *$ & & & & \\
\hline
\end{tabular}


Table A3: Heckman two stage estimate of adoption and intensity of using improved storage structure

\begin{tabular}{|c|c|c|c|c|c|c|}
\hline Variable & Coefficient & Std. Error & Prob. & Coefficient & Std. Error & Prob. \\
\hline Age & 0.002 & 0.042 & 0.961 & -0.001 & 0.009 & 0.932 \\
\hline Sex & 1.274 & 3.303 & 0.700 & 0.702 & 0.218 & 0.001 \\
\hline Years of schooling & -0.109 & 0.086 & 0.208 & -0.006 & 0.016 & 0.692 \\
\hline Household size & 0.158 & 0.114 & 0.165 & 0.026 & 0.018 & 0.147 \\
\hline Economic active household members & -0.272 & 0.203 & 0.180 & -0.049 & 0.028 & 0.077 \\
\hline Marital status & -1.209 & 1.855 & 0.514 & -0.460 & 0.274 & 0.093 \\
\hline Practice crop rotation & -0.137 & 1.033 & 0.894 & -0.106 & 0.197 & 0.588 \\
\hline Total groundnut produced & 0.000 & 0.001 & 0.771 & 0.000 & 0.000 & 0.157 \\
\hline Early harvesting of peanut & -1.151 & 2.401 & 0.632 & 0.529 & 0.254 & 0.037 \\
\hline Total groundnut affected by aflatoxin & -0.009 & 0.006 & 0.132 & -0.001 & 0.001 & 0.395 \\
\hline Total days for harvesting peanut & -0.220 & 0.176 & 0.211 & -0.018 & 0.030 & 0.540 \\
\hline Awareness of aflatoxin control & -0.134 & 2.056 & 0.948 & 0.516 & 0.241 & 0.032 \\
\hline Practice intercropping & 0.188 & 0.971 & 0.847 & -0.153 & 0.186 & 0.411 \\
\hline Cleaning of pods & 1.739 & 2.150 & 0.419 & 0.555 & 0.194 & 0.004 \\
\hline Time for harvesting peanut & 0.165 & 1.067 & 0.877 & -0.130 & 0.209 & 0.532 \\
\hline Number of days peanut is well dried & -0.113 & 0.185 & 0.540 & 0.033 & 0.026 & 0.206 \\
\hline Purchase peanut from processors & 2.869 & 1.067 & 0.007 & 0.142 & 0.200 & 0.478 \\
\hline Awareness of aflatoxin & 0.217 & 1.268 & 0.864 & -0.225 & 0.214 & 0.293 \\
\hline Storing peanut beside the house & -5.457 & 10.288 & 0.596 & 2.063 & 0.562 & 0.000 \\
\hline Storing peanut on the field & -4.998 & 9.316 & 0.592 & 1.760 & 0.569 & 0.002 \\
\hline Storing peanut in other place & -8.372 & 11.100 & 0.451 & 2.205 & 0.906 & 0.015 \\
\hline Northern region & 1.781 & 2.900 & 0.539 & 0.785 & 0.253 & 0.002 \\
\hline Upper East region & 4.682 & 3.124 & 0.134 & -0.697 & 0.293 & 0.018 \\
\hline Constant & 12.583 & 19.290 & 0.514 & -2.958 & 0.867 & 0.001 \\
\hline Inverse Mills Ratio (IMR) & 1.57397 & 6.125213 & 0.797 & & & \\
\hline Number of Observation & 319 & & & & & \\
\hline Wald chi2(23) & $48.55 * * *$ & & & & & \\
\hline
\end{tabular}




\section{List of Figures}

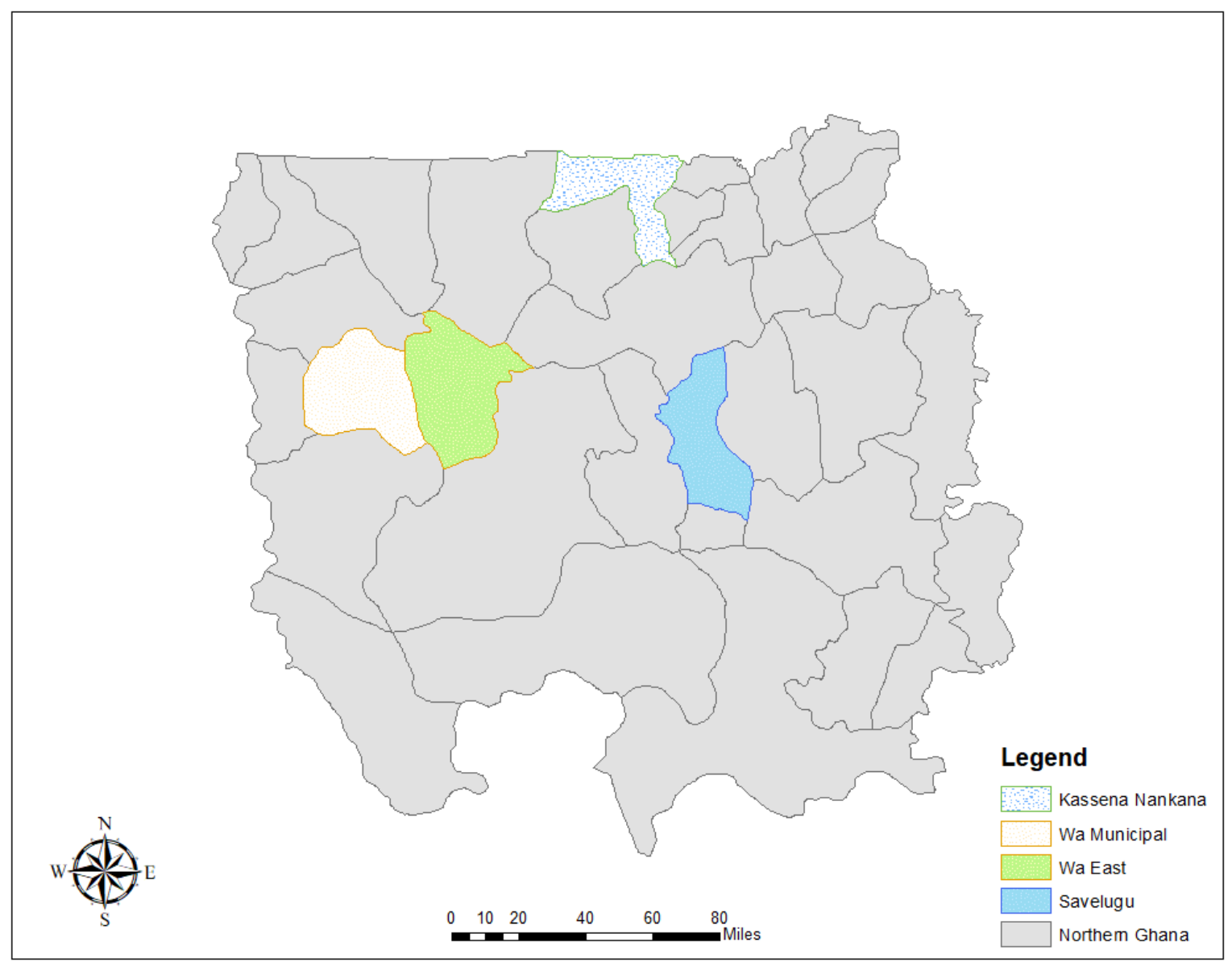

Figure 1: Map showing the study area in northern Ghana 

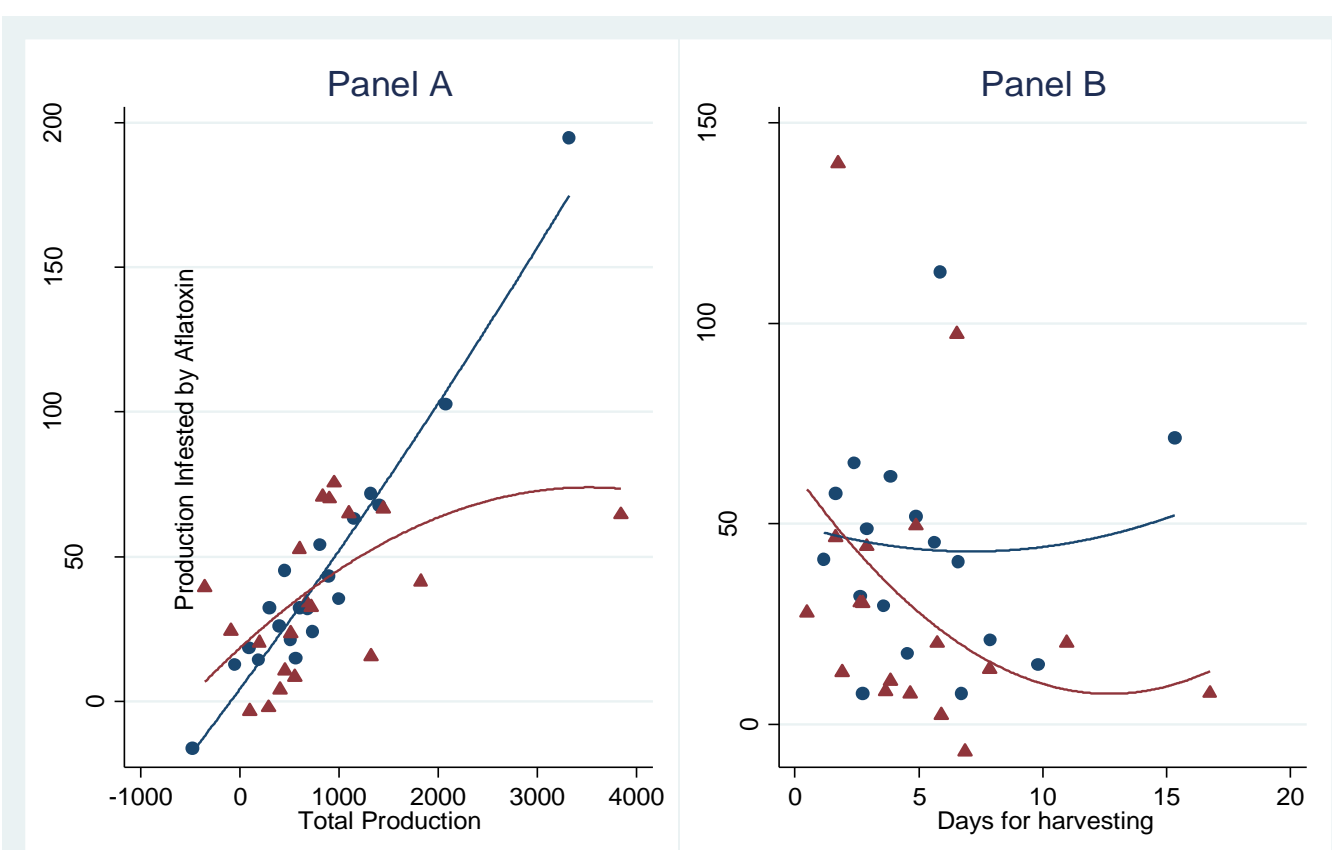

- Improved Storage $\Delta$ Traditional Storage

Figure 2: Binscatter plot of peanut produced, harvest and infested with aflatoxin

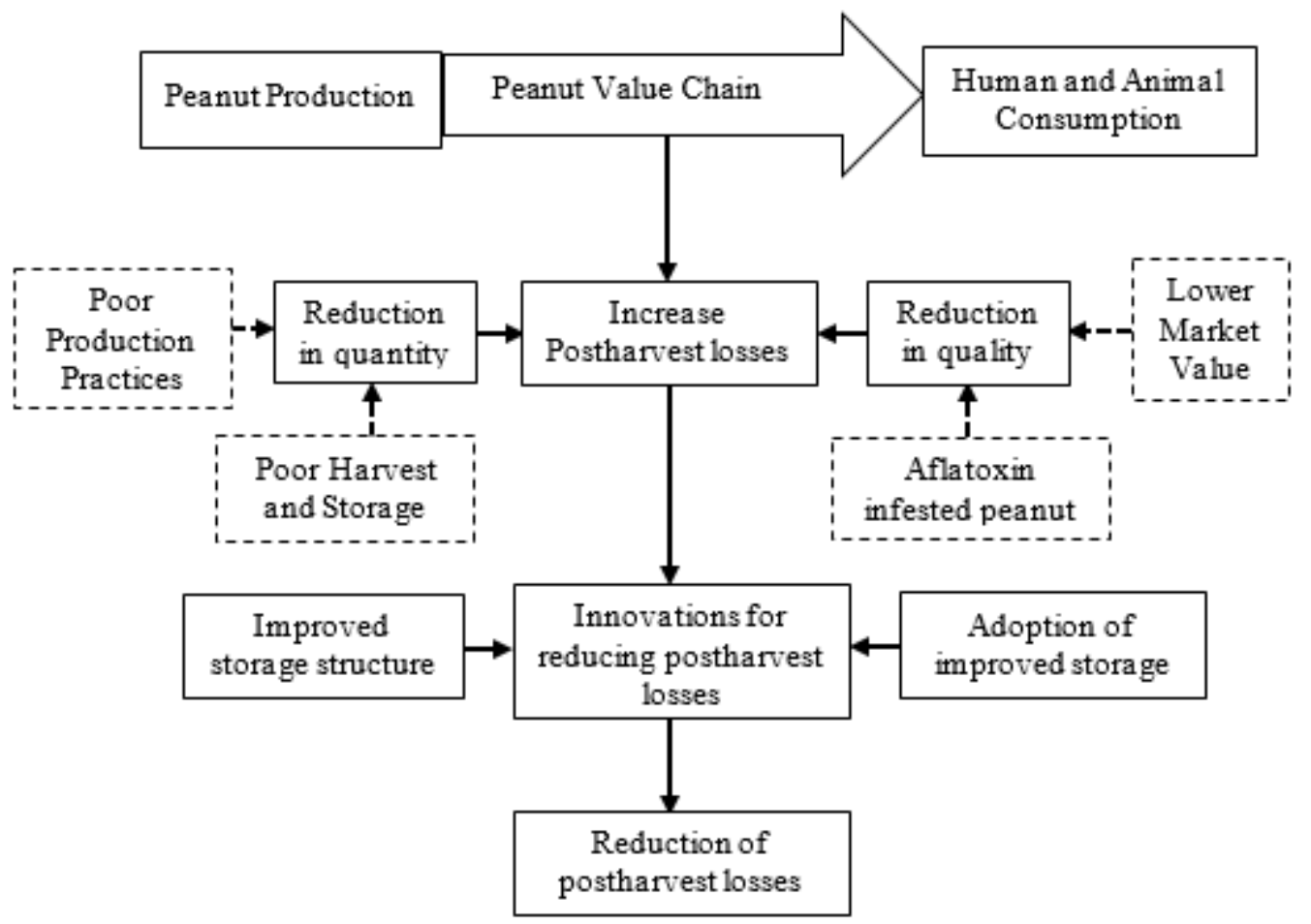

Figure 3: Conceptual framework: Peanut losses and the dynamics of control 